\title{
Rancang Bangun Sistem Informasi Pemesanan Online Aktivitas Wisata (anexplore.id)
}

\author{
Febriana Santana $^{1}$, Bagus Putu Wahyu Nirmala ${ }^{2}$, Eka Grana Aristyana Dewi ${ }^{3}$ \\ Program Studi Sistem Informasi \\ Sekolah Tinggi Manajemen Informatika dan Komputer (STMIK) Primakara \\ Denpasar, Bali \\ Email: febrianasantana20@gmail.com ${ }^{1}$, bagus.p.wahyu@gmail.com², aris@ primakara.ac.id ${ }^{3}$
}

\begin{abstract}
Abstrak-Bali merupakan salah satu tujuan wisata utama di Indonesia. Pulau Bali yang dikenal hampir di seluruh dunia menjadi salah satu destinasi favorit. Banyaknya wisatawan domestik dan mancanegara yang datang ke Bali membuat industri pariwisata di Bali berkembang pesat. Sehingga, pemandu wisata di Bali jumlahnya terbilang cukup banyak.

Adanya sistem komisi dalam dunia pariwisata memberikan peluang bagi setiap orang untuk mendapatkan penghasilan tambahan yaitu dengan cara mengajaknya untuk melakukan aktivitas wisata. Peluang tersebut tentunya memberikan dampak yang positif bagi masyarakat luas dalam menghasilkan pendapatan tambahan tanpa meninggalkan pekerjaan utamanya.

Pada penelitian ini telah dilakukan wawancara kepada reservation True Bali Experience, 63 agen tenaga lepas yang sekaligus menjadi pengguna aktivitas wisata dan 33 pengguna aktivitas wisata. Hasil wawancara yang didapat dari agen tenaga lepas mengharapkan agar proses pemesanan aktivitas wisata dapat dilakukan secara daring. Agar memudahkan pemesanan aktivitas wisata tersebut, maka pada penelitian ini dikembangkan sistem informasi pemesanan daring aktivitas wisata di Anexplore.id. Selain itu, penelitian ini juga membahas pembagian komisi bagi yang terdaftar menjadi agen tenaga lepas. Bahasa pemrograman yang digunakan dalam penelitian ini yaitu PHP dengan menggunakan metode Agile sebagai fondasi sistem. Penelitian ini berhasil mengembangkan sistem informasi pemesanan aktivitas wisata secara daring, dengan menggunakan uji fungsionalitas sistem menggunakan black box testing.
\end{abstract}

Kata Kunci: Tenaga Lepas, Agile, PHP, Pemesanan Daring

Abstract-Bali is one of the main tourist destinations in Indonesia. The island of Bali which is known to be known almost all over the world is one of the most favorite destinations. The large number of domestic and foreign tourists who come to Bali make the tourism industry in Bali grow rapidly. So, there are quite a lot of tour guides in Bali.

The existence of a commission system in the world of tourism provides an opportunity for everyone to earn additional income by inviting them to do tourism activities. These opportunities have a positive impact on the wider community in generating additional income without having to leave their main job.

In this research, interviews were conducted on the True Bali Experience reservation, 63 freelance agents who are also users of tourism activities and 33 users of tourism activities. The results of interviews obtained from freelance agents hope that the booking process for tourism activities can be done online.In order to facilitate ordering these tourism activities, this research has developed an information system for online ordering of tourism activities at Anexplore.id. In addition, this research also discusses the distribution of commissions for those who are registered as freelancing agents. The programming language used in this research is PHP using the Agile method as the system foundation. This research has succeeded in developing an information system for booking tourism activities online, using a system functionality test using black box testing.

Keywords: Freelance, Agile, PHP, Online Ordering

\section{PENDAHULUAN}

Bali atau yang juga sering disebut pulau dewata merupakan salah satu provinsi yang ada di Indonesia. Bali memiliki keragaman potensi wisata meliputi potensi wisata alam dan potensi wisata budaya disertai dengan keramahtamahan masyarakatnya menjadikan Bali sebagai daerah tujuan wisata utama di Indonesia [1]. Nama Bali bahkan telah dikenal hampir di seluruh mancanegara. Hal ini terbukti dari masuknya Bali sebagai salah satu destinasi paling favorit urutan ke lima di dunia dari 25 destinasi terbaik hasil Travelers Choice 2019 versi TripAdvisor seperti dilansir oleh IDN Times [2]. Kunjungan wisatawan mancanegara ke Indonesia juga mengalami peningkatan yang cukup signifikan dari tahun ke tahun. Badan Pusat Statistik mencatat kunjungan wisatawan mancanegara yang datang ke Indonesia secara kumulatif pada periode Januari sampai dengan September 2019 mencapai 12,27 juta kunjungan, naik 2,63 persen dibanding periode yang sama di tahun sebelumnya yang berjumlah 11,96 juta kunjungan [3].

Banyaknya wisatawan yang berkunjung ke Bali telah membuat industri pariwisata di Bali berkembang pesat dan telah banyak memberikan manfaat berupa penciptaan lapangan pekerjaan. Perkembangan pariwisata di Bali menjadikan industri ini merupakan andalan dalam perekonomian daerah 


\section{KดRMAPคTI}

dan pembangunan daerah [4]. Perkembangan industri pariwisata tentunya tidak luput dari berbagai produk berupa layanan aktivitas yang ditawarkan industri tersebut, seperti elephant riding, horse riding, watersport dan masih banyak lagi.

Indonesia terutama di Bali yang memiliki banyak destinasi wisata tentulah memiliki pemandu wisata yang jumlahnya terbilang cukup banyak. Menurut HPI (Himpunan Pramuwisata Indonesia) terdapat 3504 pemandu wisata yang berada di Bali [5]. Jumlah pemandu wisata yang terdaftar dalam HPI merupakan gabungan dari sebagian jumlah pemandu wisata lepas dan pemandu wisata pekerja tetap di penyedia layanan wisata. Pemandu wisata merupakan sebuah pekerjaan lapangan yang menuntut seseorang untuk bekerja di lokasi outdoor. Adanya sistem pemesanan aktivitas wisata secara online tentunya akan mempermudah pemandu wisata dalam melakukan pemesanan aktivitas wisata. Oleh sebab itu, penulis mengusulkan untuk membuat "Rancang Bangun Sistem Informasi Pemesanan Aktivitas Wisata Anexplore.id" untuk mempermudah dalam proses pemesanan aktivitas wisata yang ada di Bali. Tidak hanya mempermudah dalam proses pemesanan, akan tetapi juga dapat memperoleh penghasilan tambahan yaitu dengan cara menjadi guide freelance. Cara untuk menjadi guide freelance yaitu dengan mengajak wisatawan untuk melakukan aktivitas wisata, sehingga guide freelance nantinya akan mendapatkan komisi dari pemesanan tersebut. Untuk menjadi guide freelance tidaklah terpatok hanya bagi pemandu wisata saja, akan tetapi juga bisa untuk masyarakat umum. Sehingga, hal tersebut tentunya memberikan dampak yang positif bagi masyarakat luas dalam menghasilkan pendapatan tambahan tanpa meninggalkan pekerjaan utamanya.

\section{LANDASAN TEORI}

\section{A. Startup}

Startup merupakan sebuah perusahaan rintisan yang belum lama beroperasi yang dirancang untuk menciptakan produk atau jasa ditengah ketidakpastian yang ekstrem [6]. Pengembangan industri digital yang begitu pesat di Indonesia bermula pada tahun 2016 yang didukung dengan adanya kebijakan pemerintah untuk menggerakkan 1000 Startup Digital [7]. Sejak saat itulah banyak startup bermunculan di Indonesia. Banyaknya startup di Indonesia diharapkan agar dapat mendorong perekonomian di Indonesia kearah positif melalui beragam inovasi yang dihadirkan.

\section{B. Freelance}

Freelance merupakan pekerja lepas yang memiliki fleksibilitas waktu serta dapat bekerja dimanapun. Menurut Mustofa (2018) ada beberapa manfaat yang dirasakan oleh suatu perusahaan dalam merekrut freelance yaitu sebagai berikut:

1. Hemat.

Memiliki keuntungan finansial, karena perusahaan hanya membayar freelance berdasarkan proyek dalam jangka waktu tertentu, tanpa perlu membayar beragam biaya tunjangan selayaknya pegawai tetap.

2. Ide - ide kreatif.

Freelancer cenderung lebih bebas memberi masukan yang lebih objektif terhadap perusahaan yang menyewa jasanya, tanpa merasa takut terhadap struktur hierarki ataupun jenjang karier yang berdampak pada jangka waktu yang panjang.

3. Tenaga terampil.

Freelance lebih cenderung memiliki peluang waktu yang lebih banyak untuk berkembang dibandingkan dengan pegawai tetap, dikarenakan freelance tidak mempunyai ikatan pada suatu pekerjaan dan struktur tersebut. Selain itu hanya freelance yang memiliki pengetahuan luas dan berpengalamanlah yang akan unggul dalam persaingan yang ada.

4. Fleksibel.

Freelance lebih fleksibel dalam hal waktu, jangka waktu yang diberikan oleh perusahaan akan diupayakan untuk memenuhi permintaan tersebut.

5. Pelayanan

Freelance biasanya senantiasa menjaga reputasinya, demi menjaga kepercayaan dari kliennya, sehingga mereka akan berusaha untuk disiplin terhadap deadline (tenggat waktu pekerjaan). Nama baik merupakan salah satu aset penting bagi freelance, karena freelance tidak ingin reputasinya tercoreng dan tidak dipercaya lagi.

Berdasarkan manfaat di atas, tentunya keberadaan freelance dapat menjadi sebuah peluang atau kesempatan dalam dunia bisnis [8].

\section{Bahasa Permodelan $U M L$}

UML atau Unified Modeling Language merupakan bahasa permodelan standar untuk permodelan berorientasi objek. UML juga merupakan sebuah bahasa permodelan yang berdasarkan grafik atau gambar untuk memvisualisasi, menypesifikasikan, membangun, dan mendokumentasikan sebuah sistem pengembangan software berbasis ObjectOriented [9]. UML tidak hanya sekedar diagram akan tetapi juga menjelaskan konteksnya. Adapun maksud diaplikasikan UML yaitu sebagai berikut [10]:

1. Merancang perangkat lunak

2. Sarana komunikasi antara perangkat lunak dengan proses bisnis.

3. Menjabarkan sistem untuk analisis dan kebutuhan sistem. 


\section{KดRMAPดTI}

Mendokumentasi sistem yang ada, proses - proses dan organisasinya.

\section{Bahasa Pemrograman PHP}

Bahasa pemrograman merupakan prosedur penulisan dengan menggunakan aturan penulisan tertentu disertai dengan statement yang tepat ke dalam program komputer [11]. Terdapat banyak bahasa pemrograman yang muncul hingga saat ini diantaranya yaitu PHP, Java, JavaScript, C, dll. PHP (Hypertext Preprocessor) merupakan bahasa script server-side yang digunakan untuk pengembangan web, sehingga data yang ada diproses pada server terlebih dahulu [12]. PHP merupakan bahasa yang kompatibel dengan banyak server dan didukung oleh banyak platform. Selain itu PHP juga dirancang untuk membangun web yang dinamis.

\section{E. JavaScript}

JavaScript merupakan bahasa pemrograman web yang bersifat client-side, yaitu tipe bahasa pemrograman yang pemrosesannya dilakukan oleh client [13]. JavaScript berbeda dengan Java, meskipun memiliki nama yang hampir serupa. JavaScript memiliki kemampuan akses yang cukup tinggi dalam pengaksesan melalui browser, dengan menggunakan JavaScript sebuah halaman web juga akan lebih dinamis dan interaktif terhadap user.

\section{F. Basis Data MYSQL}

Basis data merupakan kumpulan dari beberapa data yang saling berhubungan yang dikelompokkan dalam sebuah atau beberapa tabel yang berisikan informasi yang nyata untuk sebuah perusahaan [14]. Basis data sangatlah penting bagi sebuah perusahaan terutama pada zaman yang serba digital saat ini yang segala data dan informasi yang dibutuhkan oleh perusahaan sudah digitalisasi. Oleh sebab itu, sebuah perusahaan wajib memiliki aplikasi yang mendukung pembuatan basis data tersebut. Saat ini banyak sekali aplikasi untuk mendukung pembuatan basis data tersebut, diantaranya yaitu MySQL, Microsoft SQL Server, Microsoft Access, Oracle dll. Pada penelitian ini penulis menggunakan MySQL dikarenakan MySQL merupakan software basis data open source yang popular, sintaknya mudah dipahami dan mendukung bahasa pemrograman PHP.

\section{METODOLOGI PENELITIAN}

Penelitian ini menggunakan metode pengembangan sistem Agile. Metode Agile merupakan metode permodelan perangkat lunak yang mengutamakan fleksibilitas terhadap perubahan-perubahan yang terjadi selama proses pembangunan perangkat lunak [15]. Penelitian ini menggunakan metode Agile dikarenakan fleksibilitasnya, dimana hasil dari analisis yang telah dilakukan diawal proyek masih dapat dilakukan perubahan tergantung dari kebutuhan sistem. Metode Agile dibagi menjadi enam tahapan yakni requirements, plan, design, development, release, dan track \& monitor.

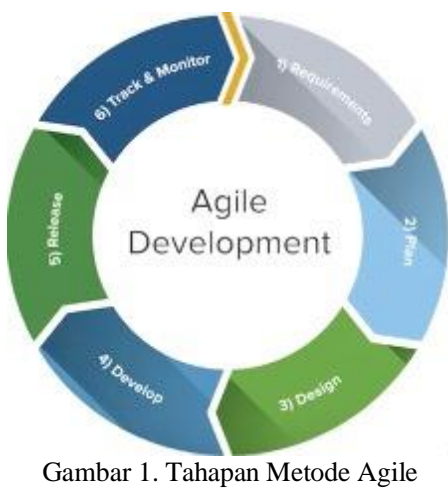

\section{A. Requirements}

Tahapan awal pengembangan sistem yaitu membahas dan mendefinisikan kebutuhan sistem. Kebutuhan sistem yang diperlukan yaitu dengan cara pengumpulan data kebutuhan, yang didapat melalui wawancara dengan berbagai pihak terkait dan mengadopsi serta membandingkan beberapa website sejenis.

\section{B. Plan}

Tahapan ini membahas apa saja yang akan dilaksanakan pada tahap pengembangan sistem. Membahas yang dimaksud dalam tahap ini yaitu mengelompokkan dan mendeskripsikan gambaran umum dari sistem yang akan dikembangkan serta membuat perkiraan waktu yang dibutuhkan dalam mengembangkan sistem. Jika dirasa beberapa kebutuhan sistem memiliki risiko yang cukup tinggi maka akan diimplementasikan terlebih dulu.

\section{Design}

Setelah tahap plan selesai, maka selanjutnya yaitu membuat rancangan sistem yang menggambarkan alur sistem berdasarkan dokumentasi yang ada. Rancangan sistem yang dibuat haruslah jelas dan detail sehingga tidak membuat sistem nantinya memiliki fungsi yang ambigu. Adapun rancangan sistem yang dibuat yaitu meliputi desain UI, arsitektur basis data dan beberapa prosedur. 


\section{KคRMดPดTI}

\section{Development}

Tahapan ini yaitu mengimplementasikan kode-kode berdasarkan desain yang telah ditentukan sehingga berbagai fitur pada sistem yang telah dikembangkan sesuai dengan fungsional dari masing-masing user.

\section{E. Release}

Tahap ini bisa dikatakan merupakan tahap peluncuran sistem yang telah dikembangkan untuk memasuki tahap testing atau pengujian fungsional sistem.

\section{F. Track \& Monitor}

Pada tahapan ini dilakukan uji coba dan evaluasi terhadap sistem untuk menyempurnakan sistem yang telah dikembangkan. Proses pengujian ini yaitu dengan menguji berbagai fitur yang ada apakah bekerja dengan fungsionalitasnya atau tidak. Selain itu tahap ini juga menguji sistem yang dikembangkan tidak terjadi bug atau berfungsi dengan baik.

\section{HASIL DAN PEMBAHASAN}

\section{A. Hasil Penelitian}

Penelitian ini melakukan wawancara kepada reservation True Bali Experience, 63 guide freelance yang sekaligus menjadi pengguna aktivitas wisata dan 33 pengguna aktivitas wisata. Pemilihan jumlah sampel pada wawancara penelitian ini mengacu pada penelitian Suharsimi Arikunto (2010) yang menyatakan bahwa jika subjeknya kurang dari 100 orang maka sebaiknya diambil semuanya, akan tetapi jika subjeknya besar atau lebih dari 100 orang maka dapat diambil $10-15 \%$ atau 20$25 \%$ atau lebih [16].

Sampel sejumlah 63 orang didapatkan berdasarkan $20 \%$ dari 315 populasi yang ada. Sedangkan populasi yang dimaksud yaitu diambil dari 4 group guide freelance yang terdiri sebagai berikut:

1.Roda Nusantara terdapat 114 guide

2.Partner Bali Tour terdapat 80 guide

3.Adashi Bali terdapat 54 guide

4.Rajawali Travel Bali terdapat 67 guide

Alasan penulis menggunakan $20 \%$ pada penentuan ukuran jumlah sampel yaitu karena:

a. Jumlah guide sebesar 315, sehingga tidak mungkin diambil semua untuk menjadi sampel.

b. Agar semua group guide freelance terwakili menjadi sampel.

c. Keterbatasan waktu dan biaya dalam proses penelitian.
Adapun teknik pengambilan sampel, dengan menggunakan teknik proportionate stratified random sampling. Teknik proportionate stratified random sampling merupakan metode pengambilan sampel dimana populasi memiliki strata secara proporsional [17]. Agar semua group guide freelance dapat terwakili, maka sampel diambil dari masing-masing group guide freelance dengan proporsi sama.

Tabel 1. Jumlah Sampel Penelitian

\begin{tabular}{|l|c|c|}
\hline \multicolumn{1}{|c|}{ Name of Group } & Jumlah guide & $\begin{array}{c}\text { Jumlah sampel (20\% dari } \\
\text { populasi) }\end{array}$ \\
\hline Roda Nusantara & 114 & 23 \\
\hline Partner Bali Tour & 80 & 16 \\
\hline Adashi Bali & 54 & 11 \\
\hline Rajawali Travel Bali & 67 & 13 \\
\hline \multicolumn{1}{|c|}{ Jumlah } & $\mathbf{3 1 5}$ & $\mathbf{6 3}$ \\
\hline
\end{tabular}

Adapun hasil wawancara dengan reservation True Bali Experience meliputi detail aktivitas wisata beserta layanan yang tersedia, data pemesanan yang dibutuhkan beserta proses pemesanannya, ketentuan jika terdapat pembatalan aktivitas wisata dan skema harga dari masing - masing layanan aktivitas wisata yang tersedia. Sedangkan hasil wawancara saat mewawancarai guide freelance yaitu proses pemesanan aktivitas wisata masih menggunakan sistem konvensional yaitu dengan cara menelpon penyedia aktivitas wisata, komisi yang didapat tidak sesuai dengan ekspektasi dan prosedur pencairan komisi yang menyulitkan. Guide freelance mengharapkan agar proses pemesanan aktivitas wisata dapat dilakukan secara online, terdapat peningkatan komisi yang didapat dan kemudahan dalam proses pencairan komisi. Adapun hasil wawancara penulis dengan pengguna aktivitas wisata yaitu rata - rata wisatawan melakukan aktivitas wisata dengan cara memesan secara online.

\section{1) Rancangan Sistem}

Sistem informasi pemesanan online aktivitas wisata (anexplore.id) dirancang menggunakan bahasa permodelan UML (Unified Modeling Language). Bahasa permodelan UML terdiri dari usecase diagram yang menggambarkan aktor dan proses secara global, activity diagram yang menggambarkan bisnis proses, dan sequence diagram yang menggambarkan alur data. 


\section{KดRMAPดTI}

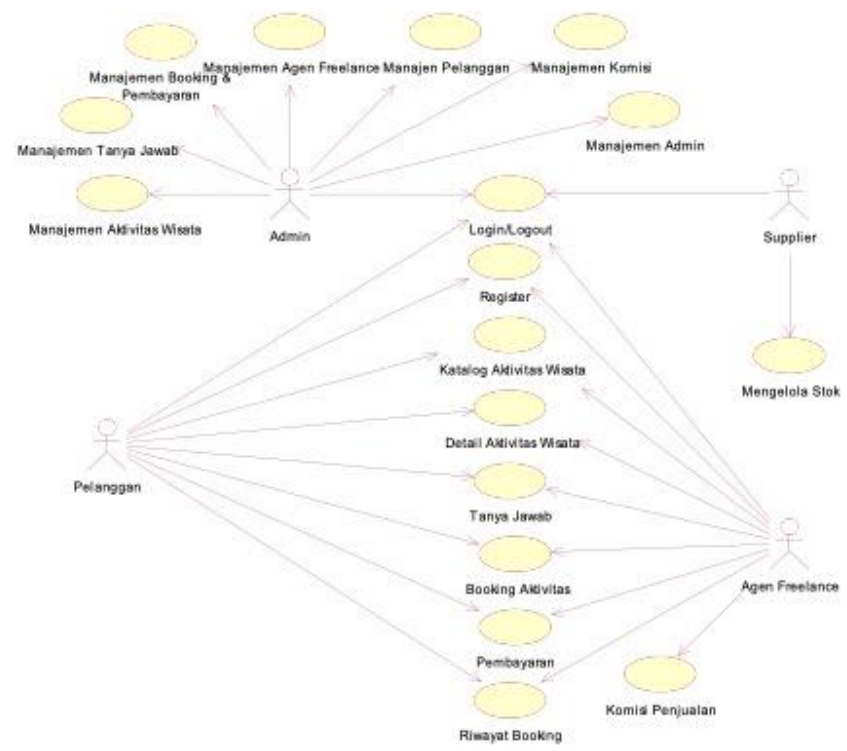

Gambar 2. Diagram usecase rancang bangun sistem informasi pemesanan online aktivitas wisata (anexplore.id)

\section{a) Proses Login}

Proses login adalah sebuah proses yang berfungsi untuk memverifikasi pengguna yang memiliki hak untuk mengakses halaman tertentu. Untuk dapat melakukan login, pengguna memasukkan data akun berupa username dan password. Apabila data akun ditemukan di basis data, pengguna dapat mengakses halaman yang dituju.

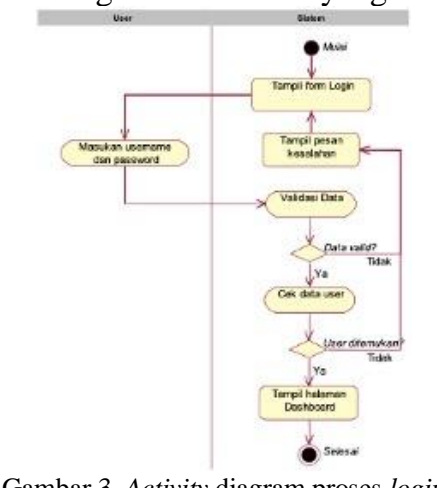

Gambar 3. Activity diagram proses login

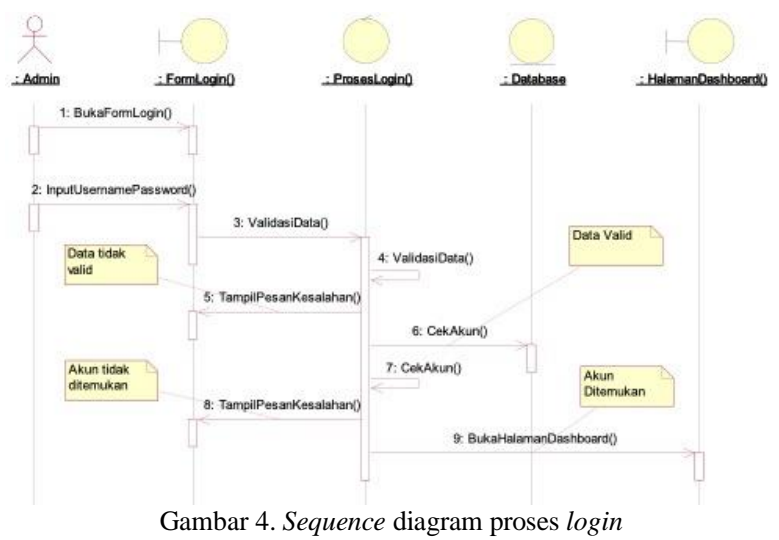

b) Proses Tambah Aktivitas Wisata

Proses tambah aktivitas wisata adalah proses yang digunakan oleh pengguna Admin untuk menambahkan aktivitas wisata ke sistem. Data yang masukkan yaitu nama aktivitas wisata, kategori, lokasi, penyedia, deskripsi, dan foto.

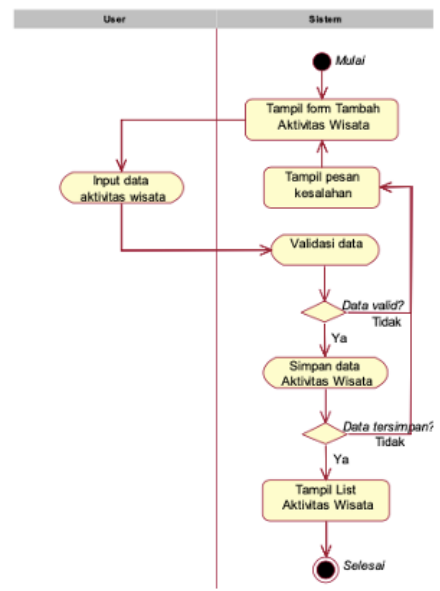

Gambar 5. Activity diagram proses tambah aktivitas wisata

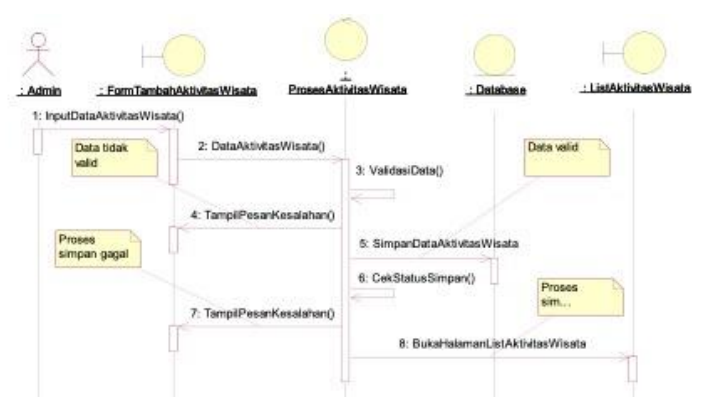

Gambar 6. Sequence diagram proses tambah aktivitas wisata

c) Proses Ubah Aktivitas Wisata

Proses ubah aktivitas wisata adalah proses yang digunakan oleh pengguna Admin untuk melakukan 


\section{KคRMAPคTI}

perubahan terhadap data aktivitas wisata. Data yang masukkan yaitu nama aktivitas wisata, kategori, lokasi, penyedia, deskripsi, dan foto.

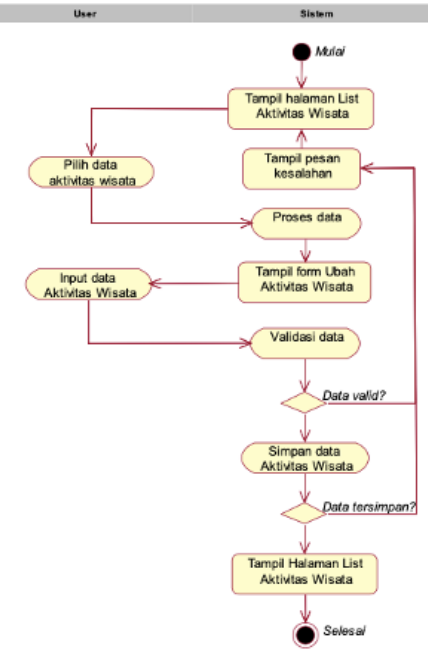

Gambar 7. Activity diagram proses ubah aktivitas wisata

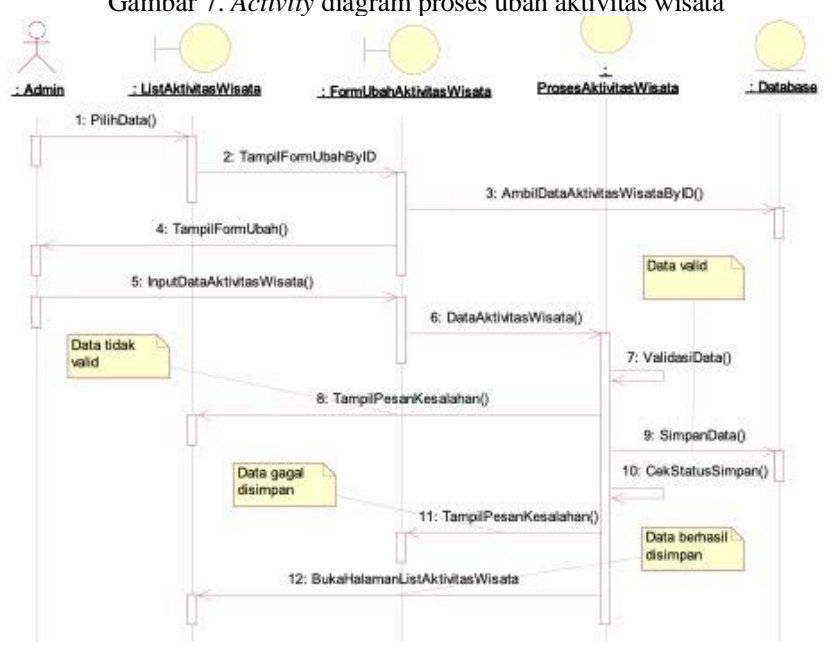

Gambar 8. Sequence diagram proses ubah aktivitas wisata

d) Proses Hapus Aktivitas Wisata

Proses hapus aktivitas wisata adalah proses yang digunakan oleh pengguna Admin untuk menghapus data aktivitas wisata. Admin memilih data yang akan di hapus pada list dan kemudian mengkonfirmasi penghapusannya.

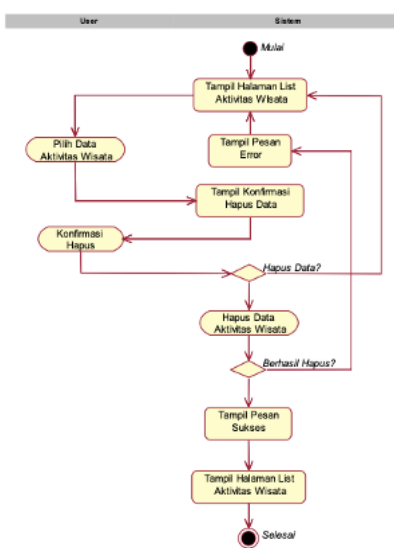

Gambar 9. Activity Diagram proses hapus aktivitas wisata

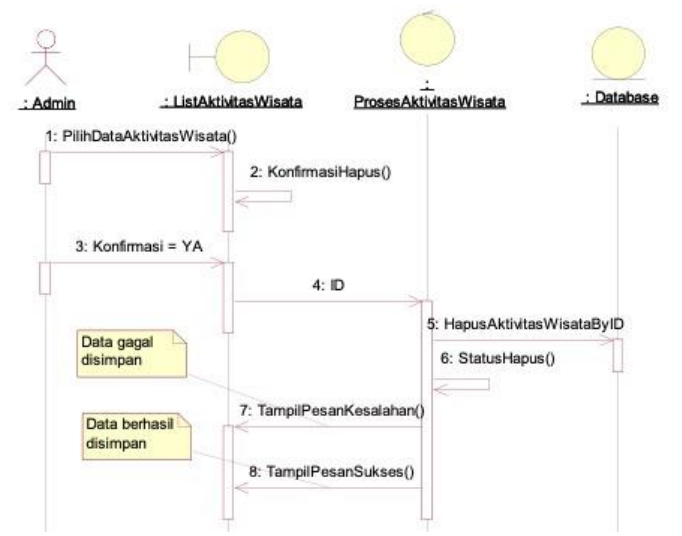

Gambar 10. Sequence diagram proses hapus aktivitas wisata

2) Rancangan Basis Data

Pada penelitian ini penulis menggunakan ERD (Entity Relationship Diagram) untuk pemetaan data. Adapun ERD dari rancang bangun sistem informasi pemesanan online aktivitas wisata (anexplore.id) dapat dilihat seperti pada gambar 11. berikut. 


\section{KARMAPATI}

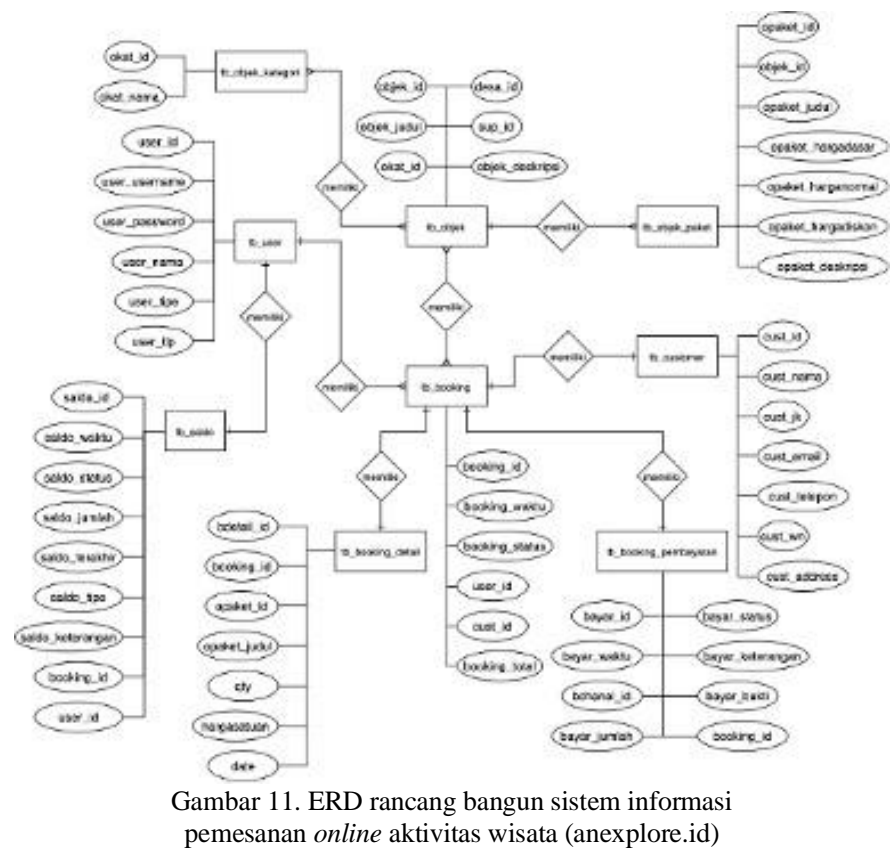

B. Pembahasan

1) Hasil Implementasi

a) Halaman untuk Publik, Customer, dan Agen Freelance

Halaman-halaman web berikut dapat diakses secara bebas oleh publik, namun untuk melakukan pemesanan harus melakukan login terlebih dahulu sebagai customer atau agen freelance.

Berikut merupakan halaman beranda yang menampilkan gambar slider dan list aktivitas wisata dari semua kategori aktivitas wisata.

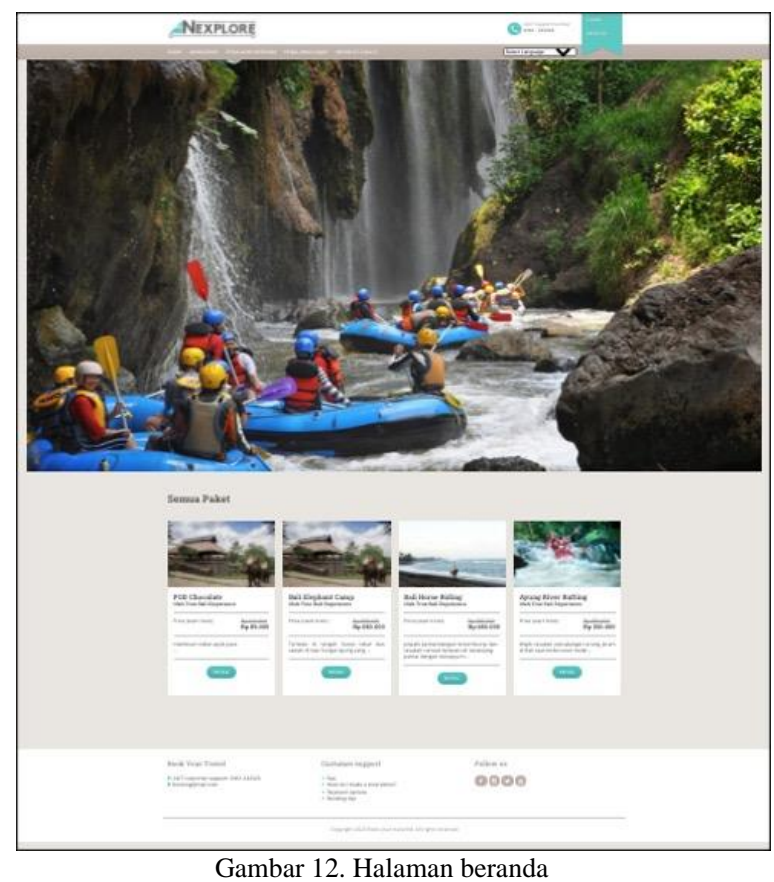

Berikut merupakan halaman list aktivitas wisata yang menampilkan list aktivitas wisata sesuai kategori yang dipilih.

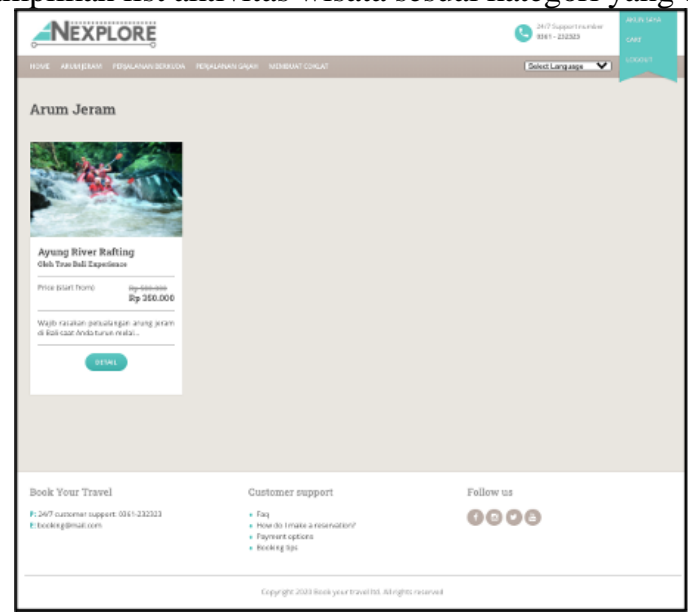

Gambar 13. Halaman list aktivitas wisata

Berikut merupakan halaman detail list aktivitas wisata yang menampilkan detail aktivitas wisata sesuai list yang dipilih. 
Kumpulan Artikel Mahasiswa Pendidikan Teknik Informatika

(KARMAPATI)

Volume 10, Nomor 2, Tahun 2021

\section{KคRMดPดTI}

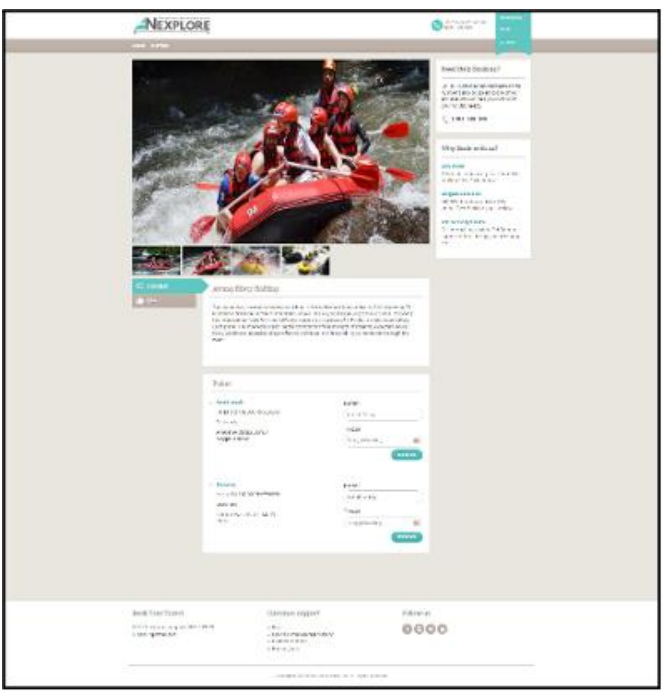

Gambar 14. Halaman detail aktivitas wisata

Berikut merupakan halaman tanya jawab aktivitas wisata yang menampilkan pertanyaan dan jawab dari customer. Selain itu, customer juga dapat mengajukan pertanyaan pada suatu aktivitas wisata.

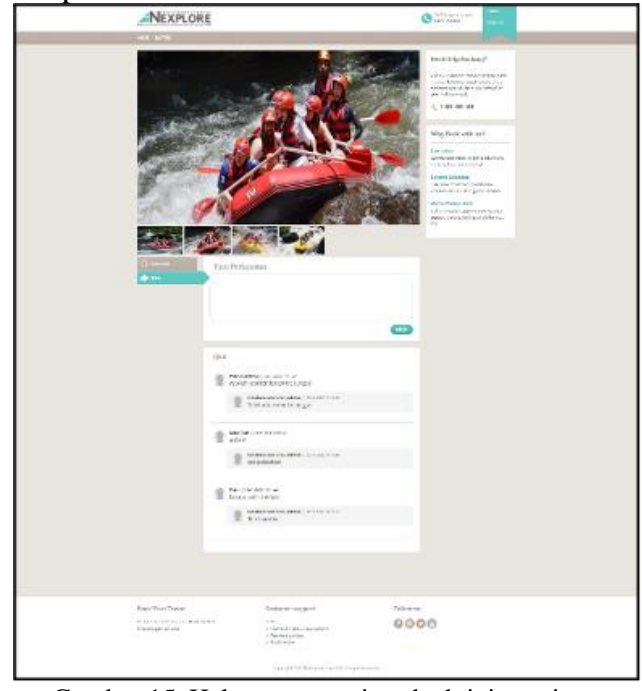

Gambar 15. Halaman tanya jawab aktivitas wisata

Berikut halaman login akun digunakan oleh pengguna yang sudah memiliki akun untuk masuk ke sistem

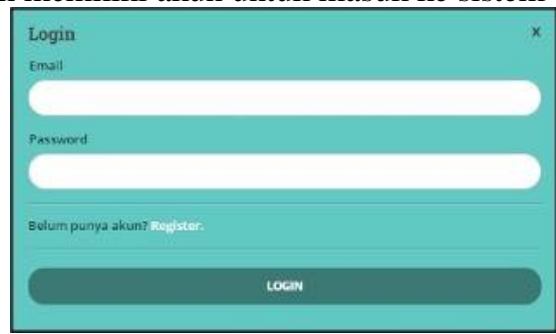

Gambar 16. Halaman login akun

Halaman register akun digunakan oleh publik yang ingin mendaftar sebagai customer atau agen freelance. Pengguna mengisi formulir secara lengkap dan kemudian menekan tombol register untuk mendaftar.

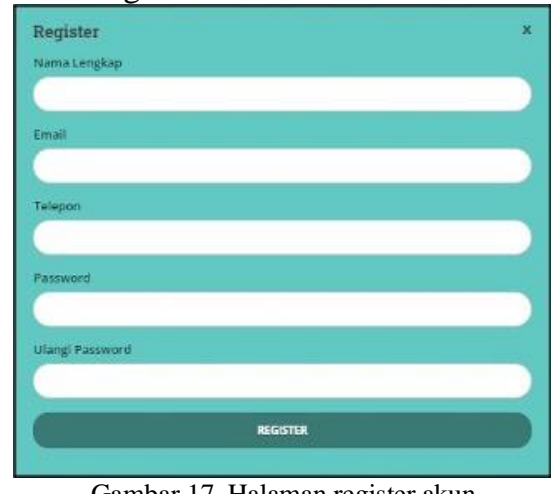

Gambar 17. Halaman register akun

Berikut merupakan halaman cart yang menampilkan daftar aktivitas wisata yang telah dipilih untuk dipesan.

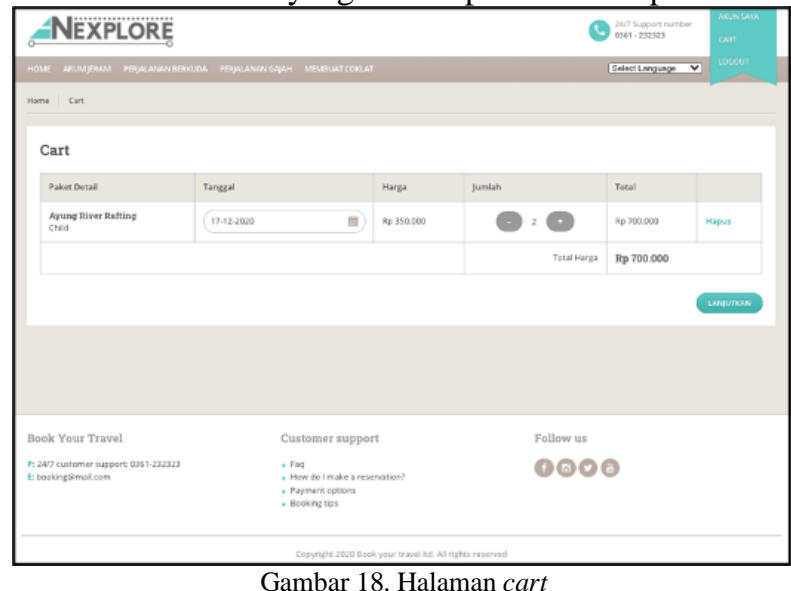

Berikut merupakan halaman checkout booking yang menampilkan aktivitas wisata yang dipilih beserta formulir data customer yang memesan. 


\section{KaRmapaTI}

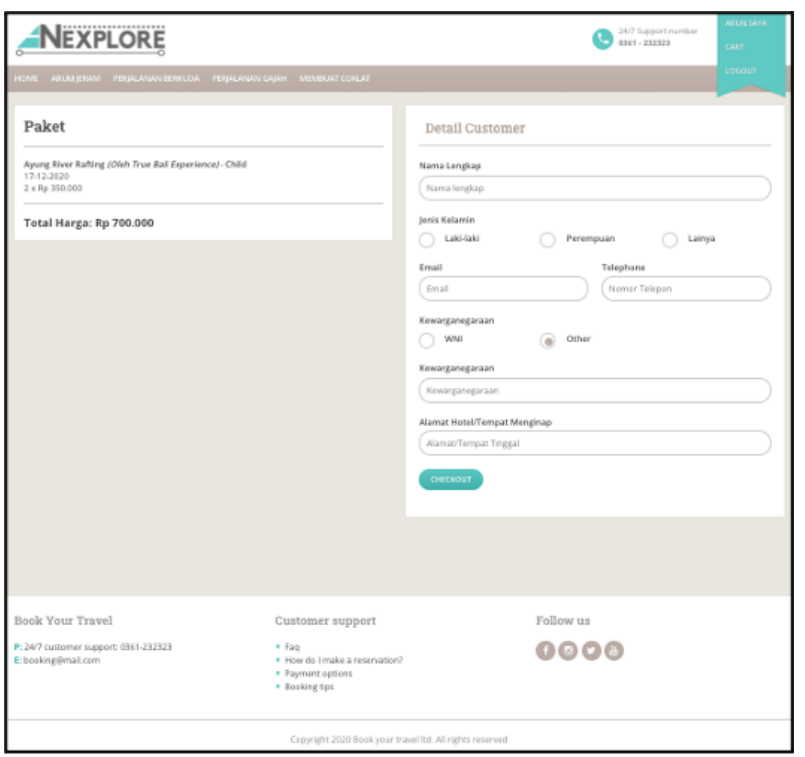

Gambar 19. Halaman checkout booking

Halaman detail booking menampilkan detail daftar pesanan yang telah dilakukan oleh customer.

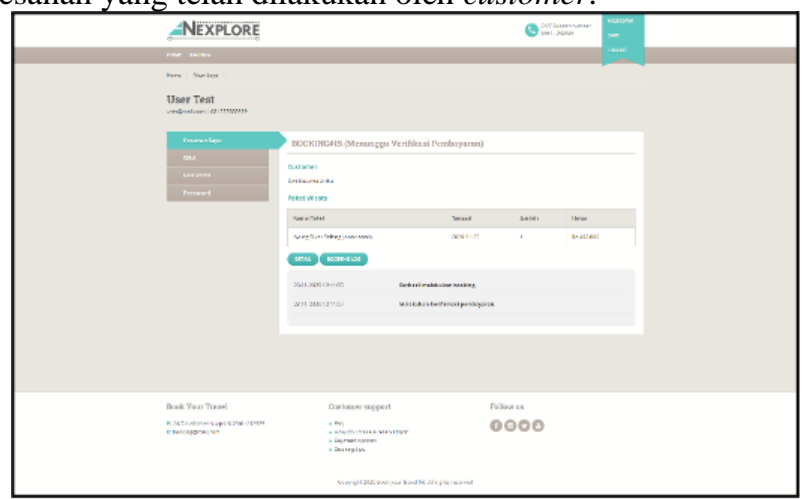

Gambar 20. Halaman detail booking

Halaman konfirmasi pembayaran dapat digunakan oleh customer untuk melakukan konfirmasi pembayaran terhadap pesanan yang telah dilakukan dengan cara meng-upload bukti pembayaran.

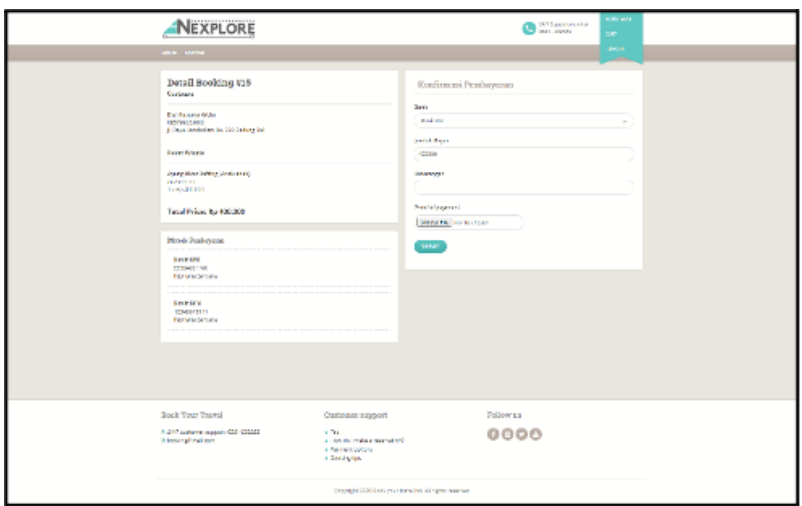

Gambar 21. Halaman konfirmasi pembayaran

Halaman pesan pribadi dapat digunakan oleh agen freelance untuk menanyakan pertanyaan terhadap aktivitas wisata yang ada.

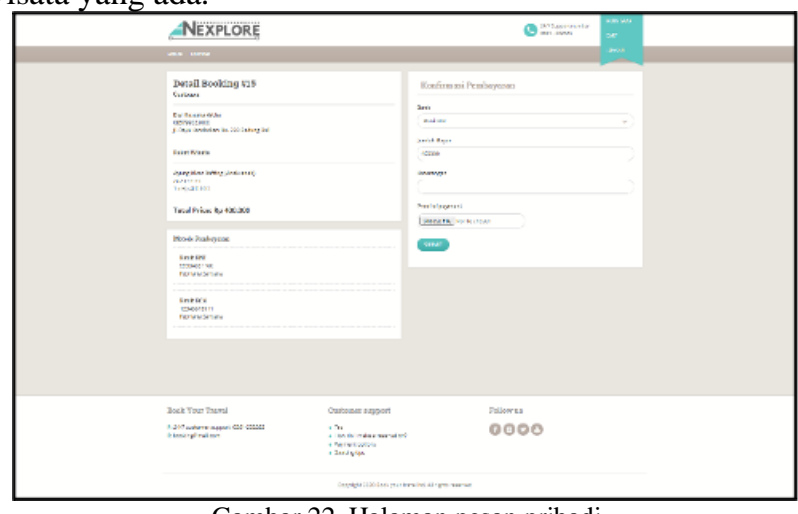

Gambar 22. Halaman pesan pribadi

b) Halaman untuk Admin

Halaman login digunakan oleh pengguna Admin untuk masuk ke sistem dengan memasukkan username dan password yang telah dimiliki.

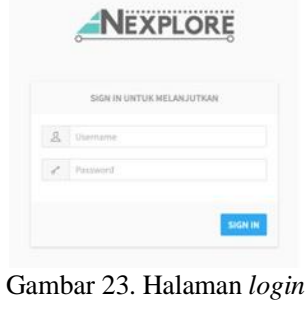

Halaman penyedia aktivitas wisata dapat digunakan oleh Admin untuk mengelola penyedia aktivitas wisata. 


\section{KดRMAPดTI}

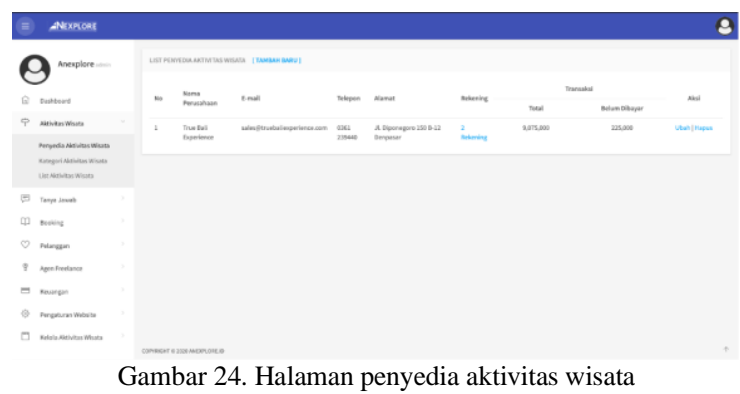

Halaman kategori aktivitas wisata dapat digunakan oleh Admin untuk mengelompokkan aktivitas wisata yang sejenis.

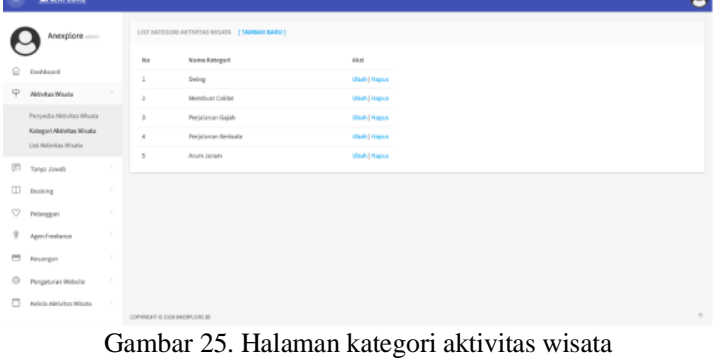

Halaman list aktivitas wisata dapat digunakan oleh Admin untuk menambahkan dan mengelola detail aktivitas wisata yang ada berupa detail aktivitas, harga, nama, lokasi dan penyedia aktivitas wisata.

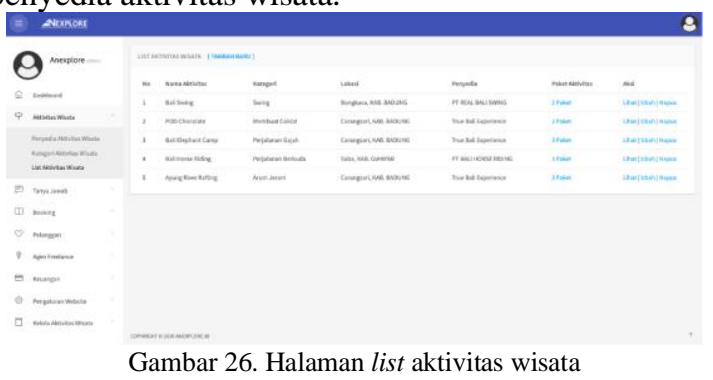

Halaman tanya jawab dapat digunakan oleh Admin untuk mengelola tanya jawab terkait aktivitas wisata.

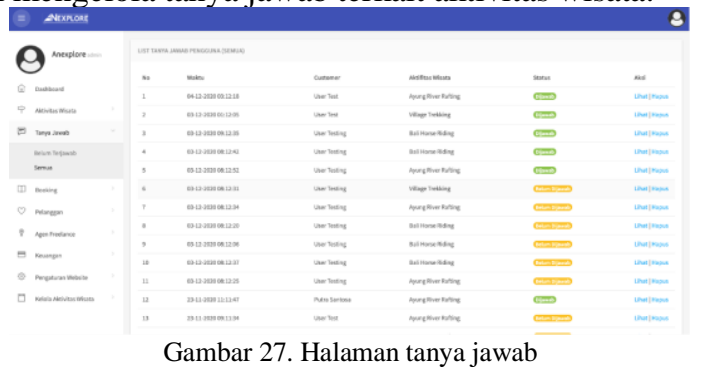

Halaman konfirmasi pembayaran dapat digunakan oleh Admin untuk mengelola konfirmasi pembayaran pesanan dari customer.

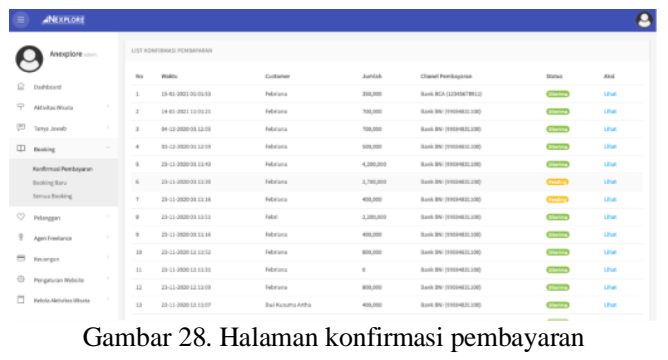

Halaman list booking dapat digunakan oleh Admin untuk mengelola pesanan dari customer.

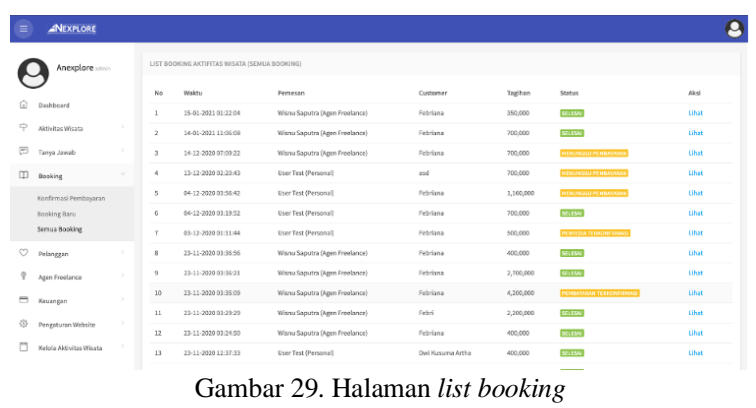

Halaman list pelanggan menampilkan daftar pelanggan yang pernah melakukan pemesanan aktivitas wisata. Pada halaman ini Admin juga dapat mengaktifkan pelanggan untuk menjadi agen freelance.

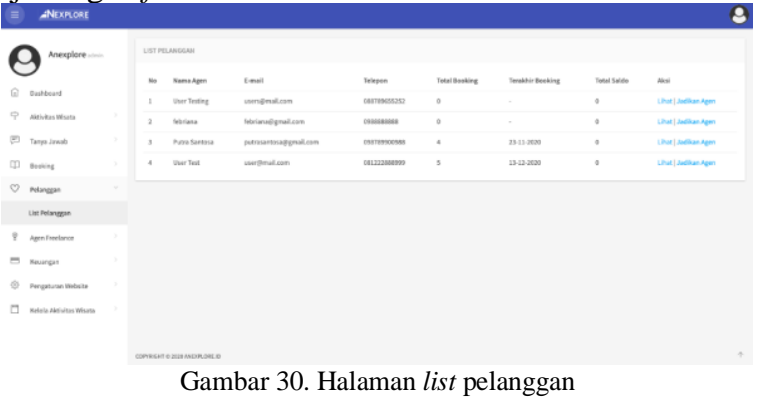

Halaman list pesan agen freelance menampilkan daftar pertanyaan yang diajukan oleh agen freelance.

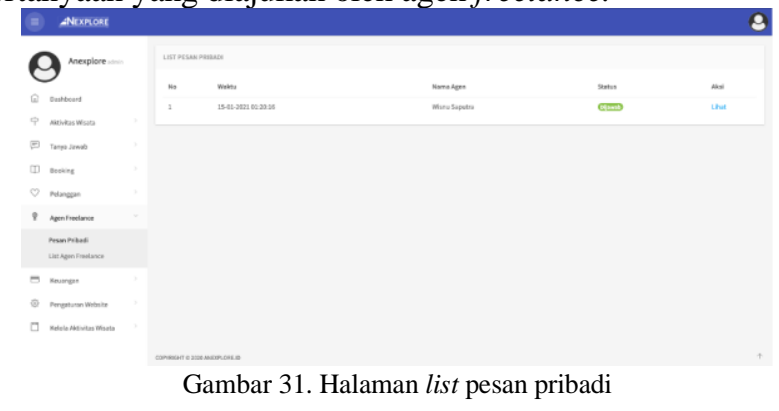




\section{KคRMดPดTI}

Halaman list agen freelance menampilkan daftar agen freelance beserta saldo komisinya. Pada halaman ini Admin juga dapat menonaktifkan akun agen freelance tersebut.

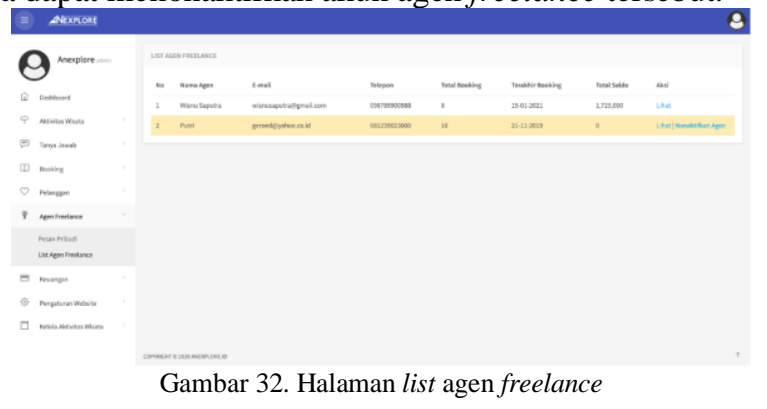

Halaman redeem saldo dapat digunakan oleh Admin untuk mengelola redeem saldo dari customer, agen freelance, dan penyedia aktivitas wisata.

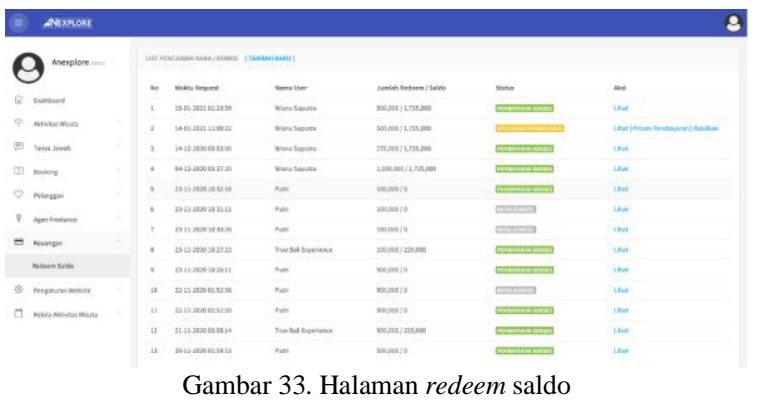

Halaman list akun dapat digunakan oleh Admin untuk mengelola seluruh akun yang terdaftar di sistem.

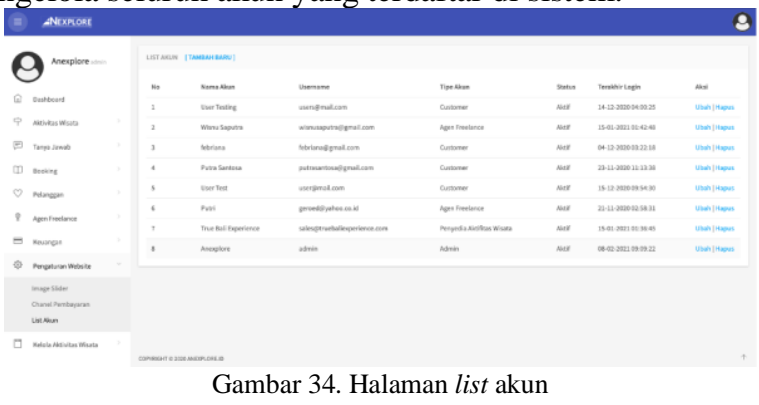

Halaman pengelolaan aktivitas wisata dapat digunakan oleh Admin untuk mengelola aktivitas wisata yang pesanannya penuh atau tidak beroperasi pada hari tertentu.

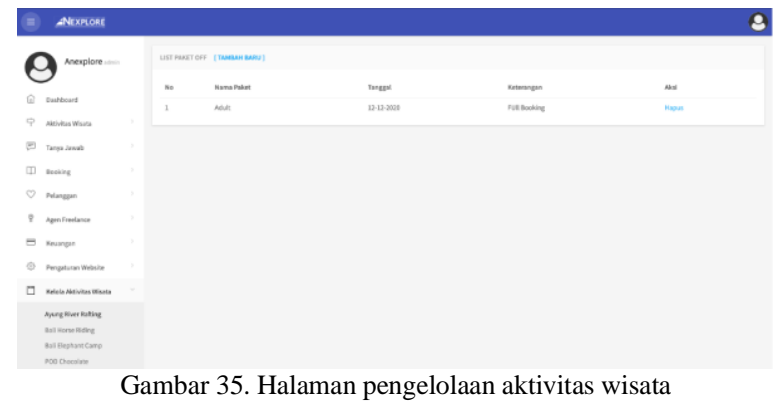

c) Halaman untuk Penyedia Aktivitas Wisata

Halaman-halaman berikut hanya dapat diakses oleh pengguna penyedia aktivitas wisata. Halaman login dapat digunakan oleh penyedia aktivitas wisata dengan memasukkan ke sistem username dan password yang sudah terdaftar.

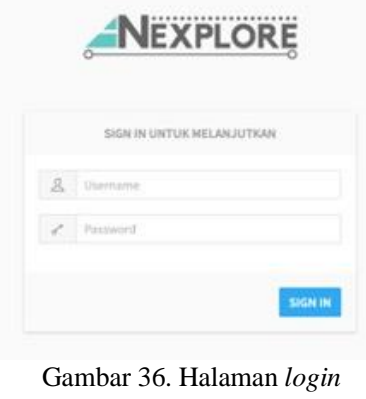

Halaman pengelolaan aktivitas wisata dapat digunakan oleh pengelola aktivitas wisata untuk mengelola jadwal pesanan yang penuh atau tidak beroperasi pada hari tertentu.

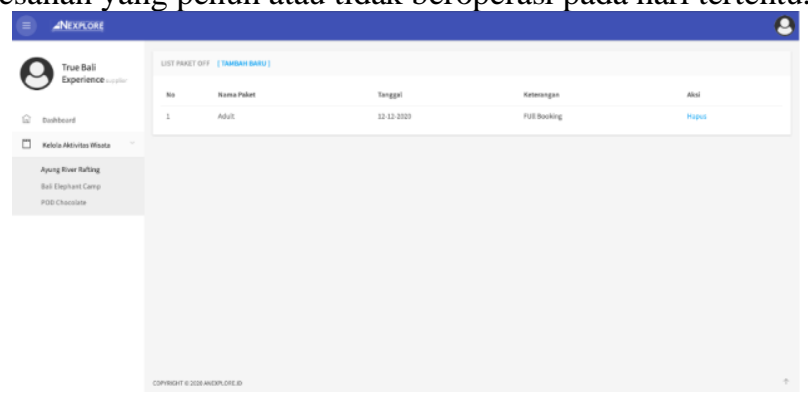

Gambar 37. Halaman pengelolaan aktivitas wisata

\section{2) Pengujian Sistem}

Tahap pengujian sistem menggunakan metode black box testing yaitu untuk menguji fungsionalitas sistem tanpa menguji kode program dari sistem. Tujuan pengujian ini yaitu untuk dapat mengetahui output dari sistem telah sesuai dengan rancangan yang telah dibuat. Berikut adalah hasil dari pengujian black box yang telah dilakukan:

Tabel 2. Pengujian Halaman User

\begin{tabular}{|c|c|c|c|}
\hline No. & Skenario & Hasil yang & Kesimpulan \\
\hline
\end{tabular}


e-ISSN: 2685-7006 | p-ISSN: 2252-9063

Kumpulan Artikel Mahasiswa Pendidikan Teknik Informatika

(KARMAPATI)

Volume 10, Nomor 2, Tahun 2021

KARMAPดTI

\begin{tabular}{|c|c|c|c|}
\hline & Pengujian & diharapkan & \\
\hline \multicolumn{4}{|c|}{ Halaman Login } \\
\hline 1 & $\begin{array}{l}\text { Mengosongkan field } \\
\text { lalu klik login }\end{array}$ & $\begin{array}{l}\text { Tidak dapat login } \\
\text { dan muncul alert }\end{array}$ & Valid \\
\hline 2 & 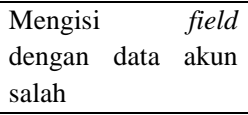 & $\begin{array}{l}\text { Tidak dapat login } \\
\text { dan muncul } \\
\text { pesan } \text { errorlalert }\end{array}$ & Valid \\
\hline 3 & 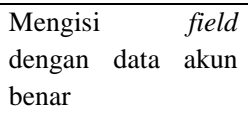 & $\begin{array}{l}\text { Berhasil login } \\
\text { dan masuk } \\
\text { halaman home }\end{array}$ & Valid \\
\hline \multicolumn{4}{|c|}{ Halaman Register } \\
\hline 1 & $\begin{array}{l}\text { Melakukan } \\
\text { registrasi menjadi } \\
\text { pengguna }\end{array}$ & User terregistrasi & Valid \\
\hline \multicolumn{4}{|c|}{ Main Menu } \\
\hline 1 & Klik Home & $\begin{array}{lr}\text { Masuk } & \text { ke } \\
\text { halaman } & \text { home } \\
\text { dan } & \text { melihat } \\
\text { seluruh } & \text { aktivitas } \\
\text { wisata } & \end{array}$ & Valid \\
\hline 2 & Klik Rafting & $\begin{array}{lr}\text { Masuk } & \text { ke } \\
\text { halaman } & \text { rafting } \\
\text { dan } & \text { melihat } \\
\text { seluruh } & \text { aktivitas } \\
\text { wisata } & \text { rafting } \\
\text { yang tersedia }\end{array}$ & Valid \\
\hline 3 & Klik Detail & $\begin{array}{ll}\text { Masuk } & \text { ke } \\
\text { halaman } & \\
\text { deskripsi } & \text { dan } \\
\text { Q\&A } & \\
\end{array}$ & Valid \\
\hline 4 & Klik Deskripsi & $\begin{array}{l}\text { Menampilkan } \\
\text { detail aktivitas } \\
\text { wisata dan } \\
\text { halaman booking }\end{array}$ & Valid \\
\hline 5 & Klik Q\&A & $\begin{array}{l}\text { Masuk ke } \\
\text { halaman } \\
\text { pertanyaan dan } \\
\text { melihat daftar } \\
\text { pertanyaan yang } \\
\text { telah terjawab }\end{array}$ & Valid \\
\hline 6 & Klik Booking & $\begin{array}{ll}\text { Masuk ke } \\
\text { halaman cart }\end{array}$ & Valid \\
\hline \multicolumn{4}{|c|}{ Halaman Cart } \\
\hline 1 & Klik Hapus & $\begin{array}{l}\text { Menghapus } \\
\text { pesanan }\end{array}$ & Valid \\
\hline 2 & Klik Lanjutan & $\begin{array}{lr}\text { Masuk } & \text { ke } \\
\text { halaman } & \text { detail } \\
\text { data pelanggan } \\
\text { dan menampilkan } \\
\text { detail paket } \\
\text { wisata }\end{array}$ & Valid \\
\hline 3 & Klik Checkout & $\begin{array}{l}\text { Pesanan berhasil } \\
\text { dibuat dan masuk } \\
\text { ke halaman akun }\end{array}$ & Valid \\
\hline
\end{tabular}

\begin{tabular}{|c|c|c|c|}
\hline & & saya. & \\
\hline \multicolumn{4}{|c|}{ Halaman Akun Saya } \\
\hline 1 & Klik Pesanan Saya & $\begin{array}{l}\text { Menampilkan list } \\
\text { pesanan }\end{array}$ & Valid \\
\hline 2 & Klik Detail & $\begin{array}{l}\text { Menampilkan } \\
\text { informasi } \\
\text { mengenai detail } \\
\text { pesanan }\end{array}$ & Valid \\
\hline 3 & $\begin{array}{l}\text { Klik Confirm } \\
\text { Payment }\end{array}$ & $\begin{array}{l}\text { Menampilkan } \\
\text { informasi dan } \\
\text { form konfirmasi } \\
\text { pembayaran }\end{array}$ & Valid \\
\hline 4 & Klik Submit & $\begin{array}{l}\text { Pembayaran } \\
\text { pesanan dalam } \\
\text { proses verifikasi }\end{array}$ & Valid \\
\hline 5 & Klik Booking Log & $\begin{array}{l}\text { Menampilkan } \\
\text { riwayat } \\
\text { pemberitahuan } \\
\text { pesanan }\end{array}$ & Valid \\
\hline 6 & Klik Q\&A & $\begin{array}{l}\text { Menampilkan } \\
\text { pertanyaan yang } \\
\text { diajukan }\end{array}$ & Valid \\
\hline 7 & Klik Edit Profile & $\begin{array}{l}\text { Data pengguna } \\
\text { berhasil } \\
\text { diperbaharui dan } \\
\text { data dalam basis } \\
\text { data berubah }\end{array}$ & Valid \\
\hline 8 & Klik Password & $\begin{array}{l}\text { Password } \\
\text { berhasil } \\
\text { diperbaharui dan } \\
\text { data dalam basis } \\
\text { data berubah }\end{array}$ & Valid \\
\hline 9 & Logout & Keluar dari akun & Valid \\
\hline
\end{tabular}

Tabel 3. Pengujian Halaman Admin

\begin{tabular}{|c|c|c|c|}
\hline No. & $\begin{array}{c}\text { Skenario } \\
\text { Pengujian }\end{array}$ & $\begin{array}{c}\text { Hasil yang } \\
\text { diharapkan }\end{array}$ & Kesimpulan \\
\hline \multicolumn{4}{|c|}{ Halaman Login } \\
\hline 1 & $\begin{array}{l}\text { Login dengan } \\
\text { akun admin }\end{array}$ & $\begin{array}{l}\text { Masuk ke halaman } \\
\text { Dashboard }\end{array}$ & Valid \\
\hline \multicolumn{4}{|c|}{ Halaman Aktivitas Wisata } \\
\hline 1 & $\begin{array}{l}\text { Klik Penyedia } \\
\text { Aktivitas Wisata }\end{array}$ & $\begin{array}{l}\text { Menampilkan } \\
\text { detail list penyedia } \\
\text { aktivitas } \\
\text { wisata dan jumlah } \\
\text { transaksi }\end{array}$ & Valid \\
\hline 2 & $\begin{array}{l}\text { Klik Tambah } \\
\text { Baru }\end{array}$ & $\begin{array}{l}\text { Menampilkan form } \\
\text { penyedia aktivitas } \\
\text { wisata }\end{array}$ & Valid \\
\hline 3 & Klik Simpan & $\begin{array}{l}\text { Detail penyedia } \\
\text { aktivitas wisata } \\
\text { baru berhasil } \\
\text { ditambahkan }\end{array}$ & Valid \\
\hline 4 & Klik Rekening & Menambahkan & Valid \\
\hline
\end{tabular}


Kumpulan Artikel Mahasiswa Pendidikan Teknik Informatika

(KARMAPATI)

Volume 10, Nomor 2, Tahun 2021

KARMAPดTI

\begin{tabular}{|c|c|c|c|}
\hline & & akun bank & \\
\hline 5 & Klik Ubah & $\begin{array}{l}\text { Mengedit detail } \\
\text { penyedia aktivitas } \\
\text { wisata }\end{array}$ & Valid \\
\hline 6 & Klik Hapus & $\begin{array}{l}\text { Menghapus detail } \\
\text { penyedia aktivitas } \\
\text { wisata }\end{array}$ & Valid \\
\hline 7 & $\begin{array}{l}\text { Klik Kategori } \\
\text { Aktivitas Wisata }\end{array}$ & $\begin{array}{l}\text { Menampilkan list } \\
\text { kategori aktivitas } \\
\text { wisata serta } \\
\text { menambah, } \\
\text { mengedit dan } \\
\text { menghapusnya }\end{array}$ & Valid \\
\hline 8 & $\begin{array}{l}\text { Klik List } \\
\text { Aktivitas Wisata }\end{array}$ & $\begin{array}{l}\text { Menampilkan, } \\
\text { mengubah dan } \\
\text { melihat list } \\
\text { aktivitas wisata } \\
\text { serta } \\
\text { menambahkan } \\
\text { aktivitas baru }\end{array}$ & Valid \\
\hline 9 & Klik Paket & $\begin{array}{l}\text { Menampilkan, } \\
\text { menambahkan, } \\
\text { mengubah dan } \\
\text { menghapus detail } \\
\text { paket aktivitas } \\
\text { wisata }\end{array}$ & Valid \\
\hline \multicolumn{4}{|c|}{ Halaman Tanya Jawab } \\
\hline 1 & $\begin{array}{l}\text { Klik Belum } \\
\text { terjawab }\end{array}$ & $\begin{array}{l}\text { Menampilkan list } \\
\text { pertanyaan yang } \\
\text { belum terjawab }\end{array}$ & Valid \\
\hline 2 & Klik Lihat & $\begin{array}{l}\text { Menampilkan dan } \\
\text { menjawab } \\
\text { pertanyaan yang } \\
\text { belum terjawab }\end{array}$ & Valid \\
\hline 3 & Klik Hapus & $\begin{array}{l}\text { Menghapus } \\
\text { pertanyaan }\end{array}$ & Valid \\
\hline 4 & Klik Semua & $\begin{array}{l}\text { Menampilkan } \\
\text { seluruh list } \\
\text { pertanyaan yang } \\
\text { terjawab atau } \\
\text { belum }\end{array}$ & Valid \\
\hline \multicolumn{4}{|c|}{ Halaman Booking } \\
\hline \multirow[t]{3}{*}{1} & $\begin{array}{l}\text { Klik Konfirmasi } \\
\text { Pembayaran }\end{array}$ & $\begin{array}{l}\text { Menampilkan list } \\
\text { pembayaran }\end{array}$ & Valid \\
\hline & Klik Lihat & $\begin{array}{l}\text { Menampilkan } \\
\text { detail pembayaran }\end{array}$ & Valid \\
\hline & $\begin{array}{l}\text { Klik Konfirmasi } \\
\text { Pembayaran }\end{array}$ & $\begin{array}{l}\text { Pembayaran } \\
\text { terkonfirmasi }\end{array}$ & Valid \\
\hline \multirow[t]{3}{*}{2} & $\begin{array}{l}\text { Klik Bookingan } \\
\text { Baru }\end{array}$ & $\begin{array}{l}\text { Menampilkan list } \\
\text { pesanan baru }\end{array}$ & Valid \\
\hline & Klik Lihat & $\begin{array}{l}\text { Menampilkan } \\
\text { detail data pesanan } \\
\text { pelanggan }\end{array}$ & Valid \\
\hline & Klik Customer & Detail pelanggan & Valid \\
\hline
\end{tabular}

\begin{tabular}{|c|c|c|c|}
\hline & Terkonfirmasi & terkonfirmasi & \\
\hline & $\begin{array}{l}\text { Klik Batalkan } \\
\text { Booking }\end{array}$ & Pesanan dibatalkan & Valid \\
\hline & $\begin{array}{l}\text { Klik Penyedia } \\
\text { Terkonfirmasi }\end{array}$ & $\begin{array}{l}\text { Pesanan } \\
\text { terkonfirmasi ke } \\
\text { penyedia aktivitas } \\
\text { wisata }\end{array}$ & Valid \\
\hline & $\begin{array}{l}\text { Klik Semua } \\
\text { Bookingan }\end{array}$ & $\begin{array}{l}\text { Menampilkan } \\
\text { seluruh bookingan }\end{array}$ & Valid \\
\hline \multicolumn{4}{|c|}{ Halaman Pelanggan } \\
\hline 1 & $\begin{array}{l}\text { Klik List } \\
\text { Pelanggan }\end{array}$ & $\begin{array}{l}\text { Menampilkan list } \\
\text { detail informasi } \\
\text { pelanggan }\end{array}$ & Valid \\
\hline \multicolumn{4}{|c|}{ Halaman Agen Freelance } \\
\hline 1 & $\begin{array}{l}\text { Klik List Agen } \\
\text { Freelance }\end{array}$ & $\begin{array}{l}\text { Menampilkan list } \\
\text { detail informasi } \\
\text { agen freelance }\end{array}$ & Valid \\
\hline & Klik Lihat & $\begin{array}{l}\text { Menampilkan data } \\
\text { agen freelance dan } \\
\text { riwayat transaksi }\end{array}$ & Valid \\
\hline \multicolumn{4}{|c|}{ Halaman Keuangan } \\
\hline 1 & $\begin{array}{l}\text { Klik Redeem } \\
\text { Saldo }\end{array}$ & $\begin{array}{l}\text { Menampilkan list } \\
\text { pencairan komisi }\end{array}$ & Valid \\
\hline & Klik Lihat & $\begin{array}{l}\text { Menampilkan } \\
\text { detail pencairan } \\
\text { dana }\end{array}$ & Valid \\
\hline & $\begin{array}{l}\text { Klik Tambah } \\
\text { Baru }\end{array}$ & $\begin{array}{l}\text { Memasukkan } \\
\text { detail akun } \\
\text { penerima komisi }\end{array}$ & Valid \\
\hline \multicolumn{4}{|c|}{ Halaman Pengaturan Website } \\
\hline 1 & Klik Image Slider & $\begin{array}{l}\text { Menampilkan, } \\
\text { menambahkan dan } \\
\text { menghapus } \\
\text { gambar slider }\end{array}$ & Valid \\
\hline 2 & $\begin{array}{l}\text { Klik Chanel } \\
\text { Pembayaran }\end{array}$ & $\begin{array}{l}\text { Menampilkan, } \\
\text { mengubah dan } \\
\text { menghapus list } \\
\text { akun bank } \\
\text { pembayaran serta } \\
\text { dapat } \\
\text { menambahkan }\end{array}$ & Valid \\
\hline 3 & Klik List Akun & $\begin{array}{l}\text { Menampilkan, } \\
\text { mengubah dan } \\
\text { menghapus list } \\
\text { akun pengguna } \\
\text { serta dapat } \\
\text { menambahkan }\end{array}$ & Valid \\
\hline \multicolumn{4}{|c|}{ Halaman Kelola Aktivitas Wisata } \\
\hline 1 & $\begin{array}{l}\text { Klik Kelola } \\
\text { Aktivitas Wisata }\end{array}$ & $\begin{array}{l}\text { Menampilkan } \\
\text { kategori aktivitas } \\
\text { wisata }\end{array}$ & Valid \\
\hline & $\begin{array}{l}\text { Klik kategori } \\
\text { aktivitas wisata }\end{array}$ & $\begin{array}{l}\text { Menampilkan, } \\
\text { menambah dan }\end{array}$ & Valid \\
\hline
\end{tabular}


2685-7006|p-ISSN: 2252-9063

Kumpulan Artikel Mahasiswa Pendidikan Teknik Informatika

(KARMAPATI)

Volume 10, Nomor 2, Tahun 2021

KคRMดPดTI

\begin{tabular}{|c|l|l|c|}
\hline & & $\begin{array}{l}\text { menghapus list } \\
\text { aktivitas wisata } \\
\text { yang tersedia } \\
\text { maupun tidak } \\
\text { tersedia }\end{array}$ & \\
\hline 1 & Klik Pengaturan & $\begin{array}{l}\text { Memperbaharui } \\
\text { data } \text { admin }\end{array}$ & Valid \\
\hline 2 & Klik Sign Out & $\begin{array}{l}\text { Keluar dari akun } \\
\text { admin }\end{array}$ & Valid \\
\hline \multicolumn{2}{|l|}{ Halaman Profil } \\
\hline
\end{tabular}

Tabel 4. Pengujian Halaman Penyedia Aktivitas Wisata

\begin{tabular}{|c|c|c|c|}
\hline \multicolumn{4}{|c|}{ Halaman Kelola Aktivitas Wisata } \\
\hline 1 & $\begin{array}{l}\text { Klik Kelola } \\
\text { Aktivitas Wisata }\end{array}$ & $\begin{array}{l}\text { Menampilkan } \\
\text { kategori aktivitas } \\
\text { wisata }\end{array}$ & Valid \\
\hline & $\begin{array}{l}\text { Klik kategori } \\
\text { aktivitas wisata }\end{array}$ & $\begin{array}{l}\text { Menampilkan, } \\
\text { menambah dan } \\
\text { menghapus list } \\
\text { aktivitas wisata } \\
\text { yang tersedia } \\
\text { maupun tidak } \\
\text { tersedia }\end{array}$ & Valid \\
\hline
\end{tabular}

\section{PENUTUP}

Berdasarkan hasil penelitian dan pembahasan pada penelitian Rancang Bangun Sistem Informasi Pemesanan Online Aktivitas Wisata (Anexplore.id), maka ditarik kesimpulan sebagai berikut:

Hasil dari perancangan dan pengembangan sistem informasi pemesanan online aktivitas wisata (Anexplore.Id) menggunakan metode Agile terdapat 4 user yaitu Admin, customer, agen freelance dan penyedia aktivitas wisata. Fitur yang terdapat dalam sistem ini pada sisi Admin adalah pengelolaan aktivitas wisata, menjawab pertanyaan, pengelolaan pemesanan, dan pengelolaan pencairan komisi. Terdapat persamaan fitur yang terdapat pada sisi customer dan agen freelance yaitu meliputi pemesanan aktivitas wisata, pembayaran aktivitas wisata, dan pencetakan tiket. Keunggulan fitur yang terdapat pada akun agen freelance dibandingkan customer yaitu terdapat saldo komisi dan penginputan rekening untuk proses pencairan komisi. Sedangkan pada pengguna penyedia aktivitas wisata terdapat fitur untuk menandai aktivitas wisata yang tidak tersedia. Hasil yang penulis dapat dengan menggunakan metode ini yaitu dapat membantu mengembangkan fitur secara bersamaan tanpa menunggu salah satu fitur selesai dibangun dengan syarat fitur tersebut tidak saling terkait. Selain itu, pengujian pada sistem dengan menggunakan black box testing telah sesuai dengan rancangan yang dihasilkan dan fitur yang diuji dari aplikasi tersebut dapat berjalan dengan baik.
Pengembangan fitur konfirmasi pembayaran belum sampai pada tahap otomatisasi. Oleh karena itu, perlu adanya pengembangan lebih lanjut. Bagi pengembang selanjutnya, diharapkan agar proses konfirmasi transaksi sudah otomatis sehingga tidak perlu lagi upload bukti transaksi secara manual.

\section{REFERENSI}

A. A. I. Andayani, E. Martono and M. Muhamad, "Pemberdayaan [1] Masyarakat Melalui Pengembangan Desa Wisata Dan Implikasinya Terhadap Ketahanan Sosial Budaya Wilayah (Studi Di Desa Wisata Penglipuran Bali)," Jurnal Ketahanan Nasional, vol. 23, no. 1, pp. 1-16, 2017.

Kanuri, "10 Destinasi Terbaik 2019 versi TripAdvisor, Indonesia Masuk 5

[2] Besar!," IDN TIMES, 2 April 2019. [Online]. Available: https://www.idntimes.com/travel/destination/nuriandika-fadila/10-destinasiterbaik-2019-versi-tripadvisor-c1c2/full. [Accessed 21 November 2019].

Badan Pusat Statistik, "Badan Pusat Statistik," 1 November 2019. [Online].

[3] Available: https://www.bps.go.id/pressrelease/2019/11/01/1617/jumlahkunjungan-wisman-ke-indonesia-september-2019-mencapai-1-40-jutakunjungan-.html. [Accessed 21 November 2019].

I. G. A. D. Yoga and I. W. Wenagama, "PENGARUH JUMLAH [4] KUNJUNGAN DAN PENGELUARAN WISATAWAN MANCANEGARA TERHADAP PRODUK DOMESTIK REGIONAL BRUTO (PDRB) PROVINSI BALI TAHUN 1996-2012," E-Jurnal Ekonomi Pembangunan Universitas Udayana, vol. 4, no. 2, pp. 71- 137, 2015.

Himpunan Pramuwisata Indonesia, "Data Anggota Pramuwisata,"

[5] Himpunan Pramuwisata Indonesia, 14 November 2016.. [Online]. Available: http://dpphpi.org/daftar-dpd. [Accessed 21 November 2019].

M. A. Jaya, R. Ferdiana and S. Fauziati, "Analisis Faktor Keberhasilan

[6] Startup Digital di Yogyakarta," in Seminar Nasional Teknologi dan Informatika (SNATIF), Kudus, 2017.

Viska, "Kominfo Luncurkan Gerakan Nasional 1000 Startup Digital,"

[7] Kementerian Komunikasi dan Informatika Republik Indonesia, 19 Juni 2016. [Online]. Available: https://kominfo.go.id/content/detail/7689/kemkominfo-bersama-kibarluncurkan-gerakan-nasional-1000-startup-digital/0/berita_satker. [Accessed 2019 November 2019].

Mustofa, "Pekerja Lepas (Freelancer) dalam Dunia Bisnis," Jurnal Mozaik, [8] vol. X, no. 1, pp. 19 - 25, 2018

Suendri, "Implementasi Diagram UML (Unified Modelling Language) Pada

[9] Perancangan Sistem Informasi Remunerasi Dosen Dengan Database Oracle (Studi Kasus: UIN Sumatera Utara Medan)," Jurnal Ilmu Komputer dan Informatika, vol. III, no. 1, pp. 1-9, 2018.

M. Muslihudin and Oktafianto, Analisis dan Perancangan Sistem Informasi [10] Menggunakan Model Terstruktur dan UML, Yogyakarta: ANDI, 2016.

E. W. Fridayanthie and J. Charter, "Rancang Bangun Sistem Informasi [11] Simpan Pinjam Karyawan Menggunakan Metode Object Oriented Programming (Studi Kasus: Pt. Arta Buana Sakti Tangerang)," Jurnal Techno Nusa Mandiri, vol. XIII, no. 2, pp. 63-70., 2016

M. Jannah, Sarwandi and C. Creative, Mahir Bahasa Pemrograman PHP, 
e-ISSN: 2685-7006 | p-ISSN: 2252-9063

Kumpulan Artikel Mahasiswa Pendidikan Teknik Informatika

(KARMAPATI)

Volume 10, Nomor 2, Tahun 2021

\section{KคRmดPคTI}

[12] Jakarta: Elex Media Komputindo, 2019.

O. Pahlevi, A. Mulyani and M. Khoir, "istem Informasi Inventori Barang

[13] Menggunakan Metode Object Oriented di Pt. Livaza Teknologi Indonesia Jakarta," Jurnal PROSISKO, vol. V, no. 1, pp. 27-35, 2018.

A. W. Widodo and D. Kurnianingtyas, Sistem Basis Data, Malang: UB

[14] Press, 2017.

R. Rahmi, R. P. Sari and R. Suhatman, "Pendekatan Metodologi Extreme

[15] Programming pada Aplikasi E-Commerce (Studi kasus Sistem Informasi Penjualan Alat-alat Telekomunikasi)," Jurnal Politeknik Caltex Riau, vol. 2, no. 2, pp. 83-92, 2016.
A. Suharsimi, Prosedur Penelitian Suatu pendekatan Praktek., Jakarta: [16] Rineka Cipta, 2010

M. N. d. R. A. P. S. Aditiya Yasmin, "ANALISIS FAKTOR-FAKTOR [17] YANG MEMPENGARUHI MAHASISWA UNTUK BERWIRAUSAHA (Studi Kasus Mahasiswa Agribisnis UIN Syarif Hidayatullah Jakarta)," Jurnal Agribisnis, vol. XII, no. 2, pp. 132 - 147, 2018. 